Vol. 7, No. 2, September 2021

P-ISSN : 2085-2487; E-ISSN : 2614-3275

Jumal Pendidikan dan Studi Islam

https://jurnal.faiunwir.ac.id/index.php/Jurnal_Risalah

\title{
EFEKTISVITAS PEMBELAJARAN DARING SAAT PANDEMI COVID-19 PADA MAHASISWA BARU (STUDI KASUS DI UNIVERSITAS MUHAMMADIYAH CIREBON)
}

\author{
Andi Ali Kisai \\ Universitas Muhammadiyah Cirebon, Cirebon 45153, Indonesia \\ E-mail: andialikisaioo@gmail.com \\ Muhammad Azka Maulana \\ Universitas Muhammadiyah Cirebon, Cirebon 45153, Indonesia \\ E-mail: aska.maulana@umc.ac.id
}

\section{Aip Syarifudin}

Universitas Muhammadiyah Cirebon, Cirebon 4513, Indonesia

E-mail: aip.syarifudin@umc.ac.id

\begin{tabular}{|c|c|c|}
\hline Received & Revised & Accepted \\
\hline 4 July 2021 & 2 Agustus 2021 & 20 September 2021 \\
\hline
\end{tabular}

\section{EFFECTIVENESS OF ONLINE LEARNING DURING COVID-19 PANDEMIC FOR NEW STUDENTS (A CASE STUDY IN UNIVERSITAS MUHAMMADIYAH CIREBON)}

\begin{abstract}
This study will describe the online learning phenomenon with an in-depth analysis of the effectiveness of online learning with a research locus at the Early Childhood Education Teacher Education Study Program (PG PAUD) FY 2020-2021 University of Muhammadiyah Cirebon (UMC). This research uses a quantitative approach with a saturated sampling technique (census) through the distribution of google form questionnaires to all new students of PG PAUD Batch 2020-2021. The study results found that the process of teaching and learning activities using the online method at the research locus was effective with several notes of recommendations. There is a common thread of messages and suggestions based on a holistic and in-depth analysis of several technical questions as a derivative of the central theme of research on the effectiveness of online learning. As a result, there is a conclusion that the rules are needed to bind the discipline of both students and lecturers as subject teachers.
\end{abstract}

Keywords: online learning, effectiveness, and Covid-19.

\section{Abstrak}

Penelitian ini akan mendeskripsikan fenomena pembelajaran daring dengan analisa mendalam mengenai efektifitas pembelajaran daring dengan lokus penelitian pada Program Studi Pendidikan Guru Pendidikan Anak Usia Dini (PG PAUD) Angkatan TA 2020-2021 
Universitas Muhammadiyah Cirebon (UMC). Riset ini menggunakan pendekatan penelitian kuantitatif dengan Teknik sampling jenuh (sensus) melalui sebaran kuisioner google form pada seluruh mahasiswa baru PG PAUD Angkatan TA 2020-2021. Didapati hasil penelitian bahwa proses kegiatan belajar-mengajar dengan metode daring di lokus penelitian bernilai efektif dengan beberapa catatan rekomendasi. Adanya benang merah catatan dan rekomendasi berdasarkan analisa secara holistik dan mendalam pada sejumlah pertanyaanpertanyaan teknis sebagai turunan dari tema besar penelitian efektifitas pembelajaran daring. Walhasil terdapat simpulan diperlukan sebuah rolles yang dapat mengikat kedisiplinan kedua belah baik mahasiswa maupun dosen sebagai pengampu mata kuliah.

Kata kunci: pembelajaran daring, efektivitas, dan Covid-19.

\section{Pendahuluan}

Metode pembelajaran daring sesungguhnya menjadi sebuah keharusan atas tuntutan zaman. Pada konteks yang lebih universal, pembelajaran daring telah menjadi tuntutan dunia sejak beberapa tahun terakhir. ${ }^{1}$ Fenomenanya dunia tengah memotret model pendidikan online sebagai rujukan penting di tahun $2025^{2}$. Menjadi sebuah keniscayaan, keharusan pembelajaran daring kian dipercepat dengan merebaknya pandemic Covid-19 mewajibkan pada semua kalangan untuk terbiasa dengan pola New Normal.

Musibah dunia Covid-19 memang telah melumpuhkan seluruh sendi aktivitas manusia. Berpengaruh pada kondisi perekonomian, sosial, politik hingga sektor pendidikan. Hingga 18 Juli 2021 data memperlihatkan kasus aktif Covid-19 hingga 527.872 orang. Meledaknya kasus aktif Covid-19 membuat pemerintah menerbitkan aturan-aturan seperti Social And Physical Distancing hingga Pembatasan Sosial Berskala Besar (PSBB $)^{3}$. Selain itu, pemerintah mengeluarkan kebijakan Pemberlakuan Pembatasan Kegiatan Masyarakat (PPKM) dengan level darurat pada 03-20 Juli dan diperpanjang hingga akhir bulan Juli 2021. ${ }^{4}$ Dengan demikian semua masyarakat Indonesia 'dipaksa' tetap berada di dalam rumah dengan konsep Work From Home (WFH). Pertanyaan kritisnya lantas bagaimana dengan keadaan pendidikan di Indonesia. Bak judul sinetron 'Maju kena- Mundur kena', dalam keadaan tidak bisa berkerumun ini Perguruan Tinggi dituntut tetap memberikan peranannya mencerdaskan kehidupan bangsa sesuai tujuan dan visi pendidikan nasional. Artinya Pembelajaran daring selain sebagai tuntutan zaman, namun juga

\footnotetext{
${ }^{1} \mathrm{He}, \mathrm{W} .$, Xu, G., \& Kruck, S. E. (2019). Online IS education for the 21st century. Journal of Information Systems Education, 25(2), 1. https://aisel.aisnet.org/jise/vol25/iss2/

2Palvia, S., Aeron, P., Gupta, P., Mahapatra, D., Parida, R., Rosner, R., \& Sindhi, S. (2018). Online education: Worldwide status, challenges, trends, and implications. https://doi.org/10.1080/1097198X.2018.1542262

3Siregar, H.S et al., 2020. Merekonstruksi alam dalam kajian sains dan agama: Studi kasus pada masa Pembatasan Sosial Berskala Besar (PSBB) dampak Covid-19. Digital Library UIN Sunan Gunung Djati Bandung.http://digilib.uinsgd.ac.id/id/eprint/30700

${ }^{4}$ https://www.suara.com/news/2021/07/16/182349/resmi-pemerintah-perpanjang-masa-ppkmdarurat-hingga-akhir-bulan-ini (diakses pada 19/07/2021)
} 
berfungsi sebagai instrumen problem solving atas kegelisahan atas musibah yang sedang melanda. ${ }^{5}$

Kendati demikian, fakta menunjukan pembelajaran daring menyimpan sejumlah persoalan. Kurang fokus dan seriusnya mahasiswa saat berlangsung kegiatan belajar-mengajar, lantaran dianggap proses daring bisa dilakukan dimana saja bahkan sembari melakukan aktivitas apapun. Situasi ini dimanfaatkan mahasiswa dengan mengerjakan aktivitas lain cukup dengan mematikan tombol audio dan tombol visual. ${ }^{6}$ Kendati demikian, fakta menunjukan pembelajaran daring menyimpan sejumlah persoalan. Kurang fokus dan seriusnya mahasiswa saat berlangsung kegiatan belajar-mengajar, lantaran dianggap proses daring bisa dilakukan dimana saja bahkan sembari melakukan aktivitas apapun. Situasi ini dimanfaatkan mahasiswa dengan mengerjakan aktivitas lain cukup dengan mematikan tombol audio dan tombol visual. ${ }^{7}$

Terlebih pada mata kuliah yang mengharuskan adanya praktikum sebagai proses pembelajaran. metode daring perlu evaluasi agar didapati formulasi penyampaiannya sehingga tujuan pembelajaran tetap didapatkan secara utuh. ${ }^{8}$ Sebuah jurnal ilmiah berjudul 'Sitematik Review: dampak perkuliahan daring saat pandemic covid-19 terhadap mahasiswa Indonesia' membeberkan dampak negatif dari pembelajaran daring diantaranya; pembelajaran daring membuat mahasiswa kebingungan, lebih pasif, kurang kreatif dan produktif, informasi yang tersendat dan pada mahasiswa menjadi kurang bermanfaat, tingginya tingkat stress mahasiswa dan peningkatan kemampuan literasi bahasa mahasiswa. ${ }^{9}$

Bertemali dengan hal tersebut, peneliti ingin melakukan sebuah riset dengan locus yang lebih fokus yakni Prodi PG Paud TA 2020-2021 di Universitas Muhammadiyah Cirebon. Terdapat beberapa alasan peneliti melakukan riset ini; pertama, mengkonfirmasi ulang sistem pembelajaran daring sejauhmana efektifitasnya. Kedua, perbedaan penelitian mengambil locus yang jelas. Ketiga, peneliti melakukan metode sensus yang akan dilakukan wawancara pada semua mahasiswa angkatan 2020-2021 Jurusan Pendidikan Guru Pendidikan Anak Usia Dini UMC. Berangkat dari hal tersebut, peneliti membuat batasan penelitian (Boundaries) pada konsep efektivitas perkuliahan daring pada masa pandemi bagi mahasiswa baru di Prodi PG Paud angkatan TA 2020-2021 Universitas Muhammadiyah Cirebon. Dengan demikian rumusan masalah yang diajukan pada penelitian ini yakni bagaimana efektivitas pembelajaran daring saat pandemi bagi mahasiswa baru di Jurusan Pendidikan Guru Pendidikan Anak Usia Dini angkatan

\footnotetext{
5Syarifudin, A. S. (2020). Impelementasi Pembelajaran Daring Untuk Meningkatkan Mutu Pendidikan Sebagai Dampak Diterapkannya Social Distancing. Jurnal Pendidikan Bahasa dan Sastra Indonesia Metalingua, 5(1), 31-34.https://doi.org/10.21107/metalingua.v5i1.7072

6https://jurnalpost.com/dilema-mahasiswa-selama-belajar-daring-di-masapandemi/23318/ (diakses 19/07/2021)

7 https://www.republika.co.id/berita/qvgkls374/optimisme-penggiat-pendidikan-tinggidi-tengah-pandemi (diakses 19/07/2021)

8 http:/ / fppb.ubb.ac.id/berita--.html (diakses 19/07/2021)

${ }_{9}^{9}$ Argaheni, Niken Bayu (2020). Sitematik Review: dampak perkuliahan daring saat pandemic covid-19 terhadap mahasiswa Indonesia. PLACENTUM Jurnal Ilmiah Kesehatan dan aplikasinya Vol 8 (2) 2020
} 
TA 2020-2021 Universitas Muhammadiyah Cirebon. Maka, peneliti ilustrasikan penelitian ini dengan kerangka berfikir sebagai berikut;

Penelitian ini bisa di ilustrasikan dengan bagan kerangka pemikiran sebagai berikut;

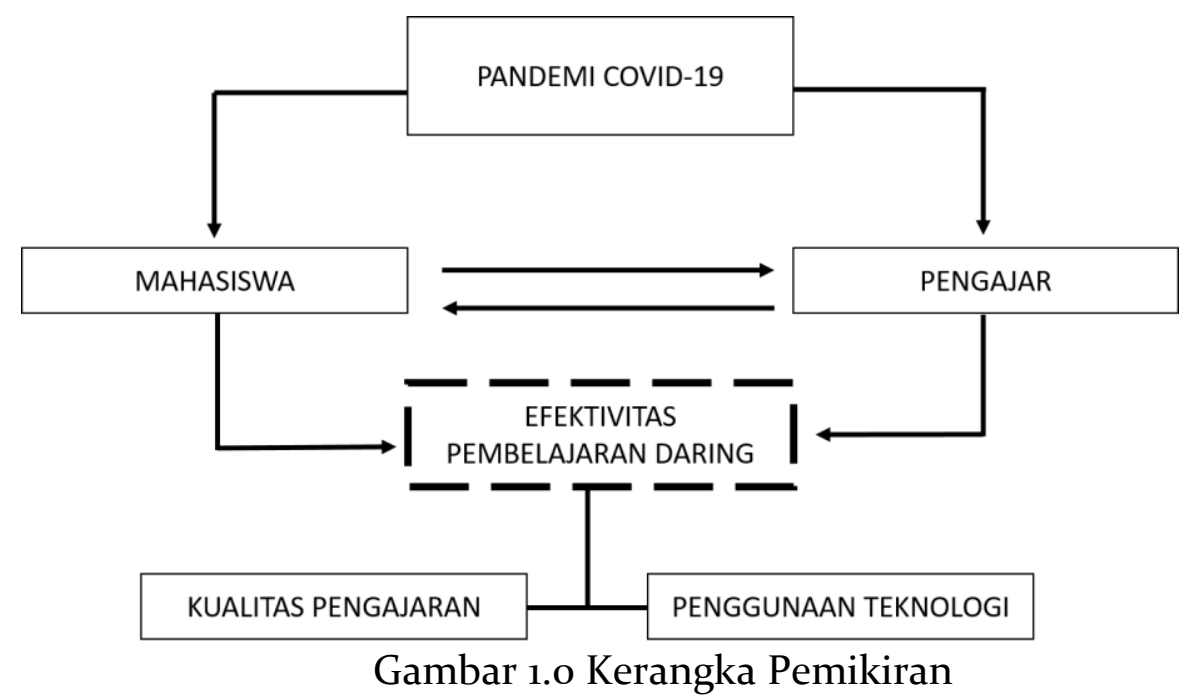

\section{Metode Penelitian}

Ada dua cara collecting data dalam ilmu statiskik, yakni sensus dan sampling. Sensus melakukan analisis data dengan cara dilakukan kepada semua responden. Hasil olahan data dalam metode sensus merupakan data yang sebenarnya (true value), dalam istilah lain disebut parameter. Sementara sampel adalah sebagian dari populasi yang memiliki karakteristik yang relatif sama dan dianggap bisa mewakili populasi. ${ }^{10}$

Sebagai sampel pada kesempatan riset ini yakni seluruh mahasiswa PG PAUD angkatan Tahun Ajaran 2020-2021 di Universitas Muhammadiyah Cirebon. Hal ini dikarenakan jumlah populasi relatif kecil yakni 96 orang. Dengan demikian teknik sampling yang dipakai dalam penelitian ini yaitu teknik sampling jenuh (sensus). Artinya semua mahasiswa yang dalam hal ini adalah sebagai anggota populasi digunakan sebagai sampel."

Data primer diperoleh dari kuesioner yang dikirim secara online kepada 96 responden yakni mahasiswa baru Universitas Muhammadiyah Cirebon (UMC) pada Jurusan Pendidikan Guru Pendidikan Anak Usia Dini (PAUD) angkatan TA 20202021. Data diperoleh melalui isian pertanyaan dalam bentuk google form yang selanjutnya dapat di kumpulkan, dianalisa, diinterpretasi dan dideskripsikan.

Berbagai Komponen yang akan digali dalam rumusan kuesioner dengan metode survei antara lain;

1. Dimanakah mahasiswa biasanya mengikuti perkuliahan metode daring selama pandemi Covid-19

\footnotetext{
10 Sugiyono, 1999. Metode Penelitian Administrasi. Edisi kedua. Bandung: Alfabeta

11 Sugiyono, 2014. Metode Penelitian Pendidikan Pendekatan Kuantitatif, Kualitatif dan R\&D.

Bandung. Alfabeta
} 
2. Jenis koneksi internet apa yang sering mahasiswa gunakan selama perkuliahan metode daring

3. Bagaimana keadaan kondisi sinyal internet dilokasi yang mahasiswa pergunakan dalam perkuliahan daring

4. Media apa yang mahasiswa gunakan pada saat pelaksanaan perkuliahan daring

5. Aplikasi apa yang menurut mahasiswa efektif digunakan dalam perkuliahan daring

6. Apakah menurut mahasiswa perkuliahan daring (online) pada saat Pandemi Covid-19 efektif

7. Jenis perkuliahan seperti apa yang diharapkan mahasiswa selama pandemi Covid-19

8. Kendala apa yang mahasiswa hadapi pada saat pelaksanaan perkuliahan metode daring

9. Apakah mahasiswa sudah siap terhadap aturan baru the new normal live (tatanan hidup baru) selama berlangsungnya perkuliahan metode daring.

10. Apakah mahasiswa memahami materi apa yang diajarkan oleh dosen

11. Apakah dosen terlihat kesulitan saat menggunakan pembelajaran daring

12. Apakah mahasiswa sering aktif dan terlibat dalam pembelajaran daring (diskusi)

13. Berapa lama durasi yang digunakan dosen selama pembelajaran metode daring Pada kesempatan penelitian ini, untuk mempermudah proses penelitian dan dalam upaya mendapatkan hasil penelitian yang akurat, maka peneliti menggunakan road map yang di desain secara sistematis sesuai dengan kaidah dalam penelitian. Rangkaian proses dalam penelitian ini bisa dilihat dalam skema pada gambar dibawah ini.

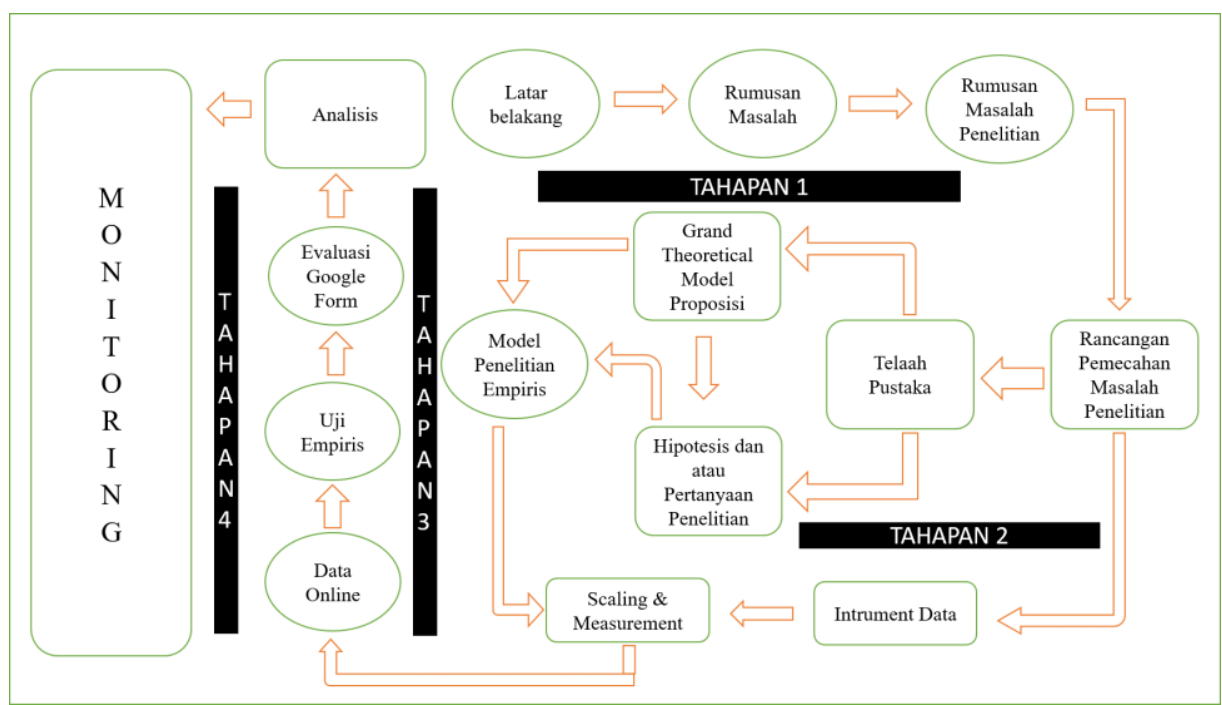

Gambar 2.Road Map Penelitian. 


\section{Hasil Penelitian dan Pembahasan Efektifitas Pembelajaran Daring}

Sebagai kacamata dalam menganalisa, peneliti bersandar pada asumsi ahli mengenai efektifitas. ${ }^{12}$ memberikan penjelasan bahwa efektivitas merupakan jangkauan usaha suatu program sebagai suatu sistem dengan sumber daya dan sarana tertentu untuk memenuhi tujuan dan sasarannya tanpa melumpuhkan cara dan sumber daya itu serta tanpa memberi tekanan yang tidak wajar terhadap pelaksanaannya. Jelas bisa kita simpulkan dalam konteks penelitian ini yang akan menakar efektifitas pembelajaran daring maka tujuan dan sasaran tidak boleh lumpuh atau berkurang makna, fungsi, dan tujuannya. Artinya pembelajaran daring harus tetap menjamin mahasiswa mendapat kesimpulan atas semua materi yang di sajikan oleh para dosennya.

Secara bangunan konsep pembelajaran daring merupakan salah satu bentuk pemanfaatan dari teknologi informasi dengan maksud meningkatkan partisifasi mahasiswa dalam proses pembelajaran ${ }^{13}$. Keuntungan pembelajaran online adalah pembelajaran bersifat mandiri dan interaktivitas yang tinggi, memberikan lebih banyak pengalaman belajar, dengan teks, visualisasi audio dan video dan animasi yang digunakan untuk menyampaikan informasi dalam pembelajaran. Selain itu, metode daring juga mendatangkan kemudahan dalam menyampaikan, memperbarui isi, mengunduh, para mahasiswa saling berkirim email kepada mahasiswa lain, berdiskusi di dunia maya, memakai room chat, sampai pada fasilitas tatap muka dalam dunia maya atau video Conference. ${ }^{14}$ Seperti disinggung sebelumnya pembelajaran daring adalah sebuah tuntutan zaman bukan sekedar karena fenomena hari ini diselimuti pandemic Covid-19, jauh dari itu adalah sebuah model pendidikan dunia.

Meskipun demikian, menjadi catatan perihal ini adalah pada persoalan teknis pembelajaran metode daring. Pembelajaran memerlukan adanya kematangan dalam merencanakan, pembuatan perangkat pembelajaran (media), model pembelajaran (materi), hingga evaluasi pembelajaran. Adanya penggunaan model-model pembelajaran yang efektif dan inovatif (visualisasi) agar saat proses pembelajaran variatif dan berjalan lancar. Disamping itu etika dan kedisipnilan dalam proses belajar mengajar sangat diperlukan demi tercapainya tujuan penyelenggaraan pendidikan.

Sebelum mengulas bagaimana hasil penelitian mengenai efektifitas pembelajaran daring pada Prodi PG PAUD Universitas Muhammadiyah Cirebon (UMC), peneliti sajikan terlebih dahulu hasil-hasil penelitian yang mengangkat tema pembelajaran daring. Terdapat banyak hasil riset yang mengangkat mengenai

\footnotetext{
12Steers (1985:87) Efektivitas Organisasi Kaidah Perilaku (Alih bahasa Magdalena). Jakarta: Erlangga

13Saifuddin, M. F. (2016). E-Learning Dalam Persepsi Mahasiswa. Universitas Ahmad Dahlan. 102110.

${ }^{14}$ Arnesti, N., \& Hamid, A. (2015). Penggunaan Media Pembelajaran Online - Offline Dan Komunikasi Interpersonal Terhadap Hasil Belajar Bahasa Inggris. Jurnal Teknologi Informasi \& Komunikasi Dalam Pendidikan, 2(1). https://doi.org/10.24114/jtikp.v2i1.3284.
} 
pembelajaran metode daring, diantaranya $;^{15}$ menjelaskan bahwa kedua aplikasi Zoom dan Whatsapp hanya akan efektif bagi mata kuliah teori sedangkan diluar mata kuliah teori atau praktek secara online dirasa tidak efektif. Penelitian lain yakni W Darmalaksana ${ }^{16}$ dengan menunjukan efektifnya KBM secara daring dengan capaian yang tinggi dan signifikan seiring adanya tuntutan mewujudkan pemimpin digital pendidikan tinggi abad 21, meskipun saat dilaksanakan pada masa Work From Home (WFH) yang disebabkan mewabahnya pandemic Covid-19. Jurnal Sistemik Review membeberkan fakta-fakta tentang dampak pandemi bagi peserta didik seperti yang sudah peneliti ulas diatas, hal ini cukup memprihatinkan.

Mengkaji hasil-hasil riset sebelumnya, peneliti berharap hasil penelitian yang dilakukan pada kesempatan ini dapat melengkapi khasanah kajian mengenai pembelajaran daring. Terlebih, peneliti merasa gelisah dengan sejumlah penelitian yang mengatakan bahwa pembelajaran daring dikatakan tidak efektif. Riset ini akan mengulas seberapa efektifnya pembelajaran daring dengan lokus yang spesifik yakni Program Studi PG PAUD UMC dengan angkatan TA 2020-2021. Adapun temuantemuan dari penelitian ini sebagai berikut:

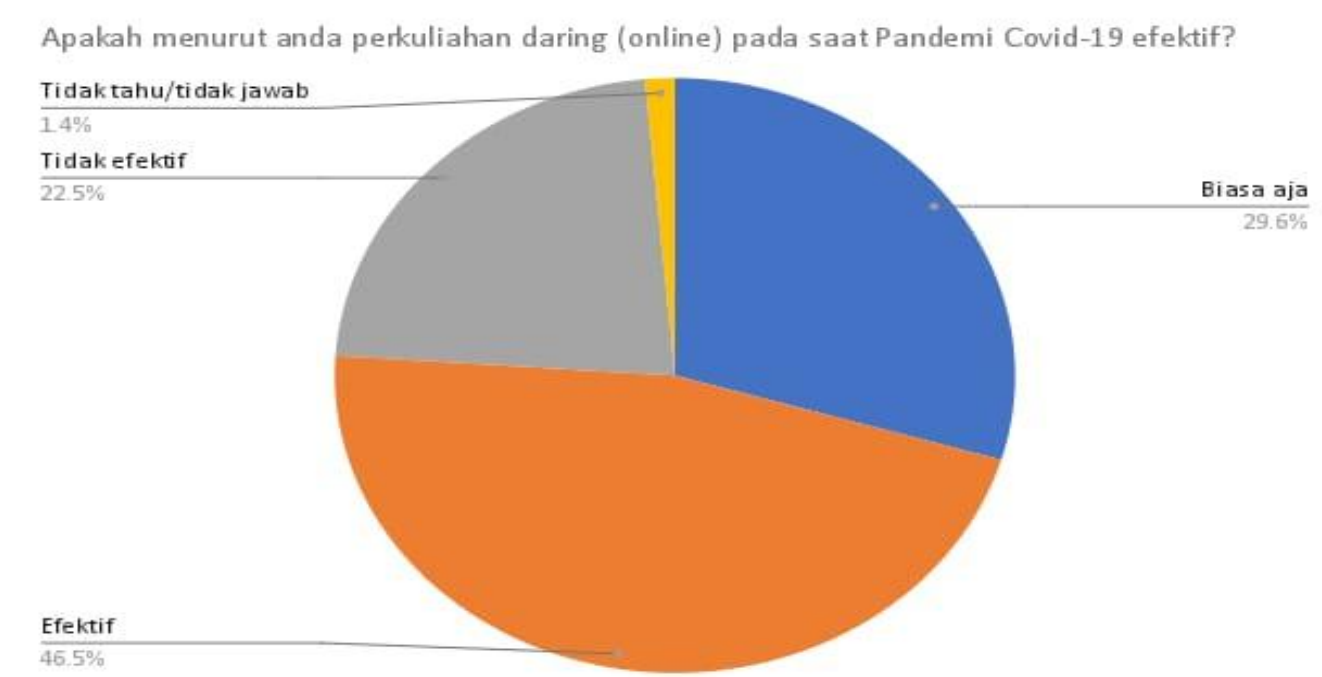

Responden menjawab efektif menempati posisi $46,5 \%$ disusul yang menjawab tidak efektif $22,5 \%$, biasa saja $29,6 \%$ dan sisanya responden menjawab tidak tahu/tidak jawab. Dengan demikian mahasiswa baru program studi Pendidikan Guru Pendidikan Anak Usia Dini TA 2020-2021 UMC mayoritas merasakan pembelajaran daring efektif.

Pada point berikutnya peneliti mencoba mengulas kembali dengan sejumlah konten pertanyaan lain namun dengan kesamaan substansi. Hal ini difungsikan untuk menarik benang merah bahwa benar apakah terjadi efektifitas ataupun tidak

\footnotetext{
${ }^{15}$ Hikmat., Hermawan, Endang., Aldim., Irwandi. (2020). Efektivitas Pembalajaran Daring Selama Masa Pandemi Covid-19: Sebuah Survey Online. UIN Sunan Gunung Djati Bandung. http://digilib.uinsgd.ac.id/id/eprint/30625

${ }^{16}$ Darmalaksana, W., Hambali, R., Masrur, A., \& Muhlas, M. (2020). Analisis Pembelajaran Online Masa WFH Pandemic Covid-19 sebagai Tantangan Pemimpin Digital Abad 21. Karya Tulis Ilmiah (KTI) Masa Work From Home (WFH) Covid-19 UIN Sunan Gunung Djati Bandung, 1-12. http://digilib.uinsgd.ac.id/id/eprint/30434
} 
versi responden. Peneliti menampilkan pertanyaan mengenai kepuasan atas proses pembelajaran daring selama ini. Sinergis dengan data sebelumnya pada pokok poin ini dapat terlihat pada diagram sebegai berikut;

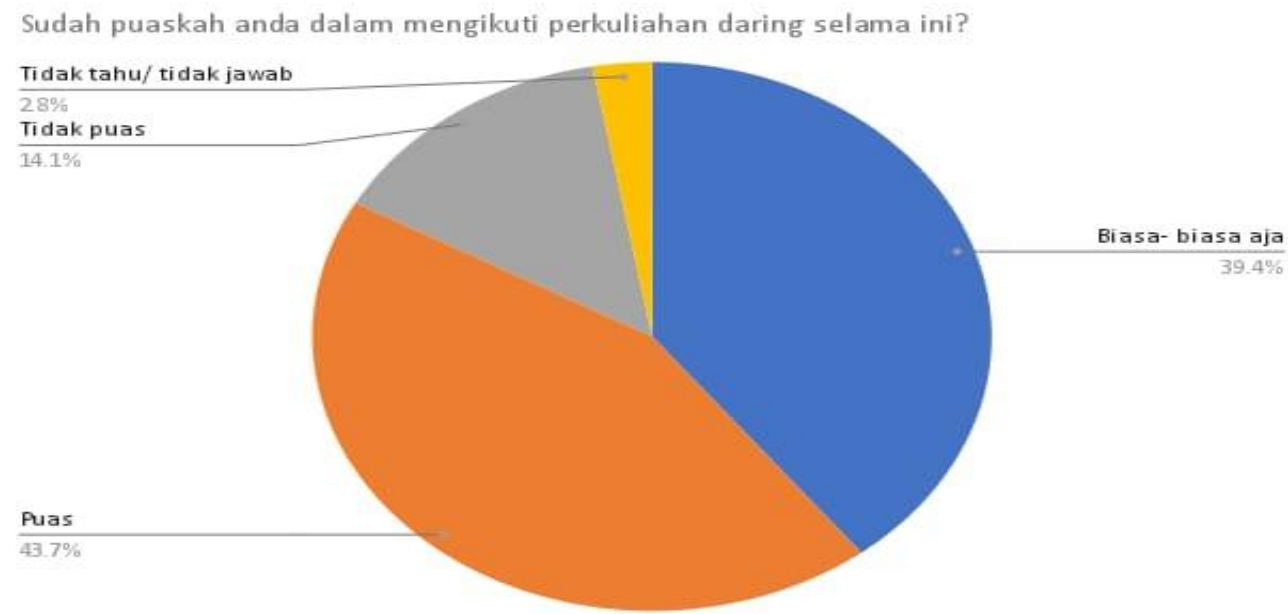

Pada diagram diatas dapat disimpulkan bahwa mayoritas mahasiswa mengatakan puas pada kegiatan pembelajaran daring. Total mahasiswa yang mengatakan puas sejumlah $43,7 \%$, disusul 39.4\% mahasiswa mengatakan biasa-biasa saja, kemudian $\mathbf{1 4 , 1} \%$ mengatakan tidak puas atas pembelajaran daring. Fakta ini memperkuat asumsi peneliti bahwa proses pembelajaran daring berjalan secara efektif.

Pada substansi materi, peneliti juga menyajikan pertanyaan dengan maksud menarik kesimpulan apakah mahasiswa dapat memahami materi secara baik dalam pembelajaran daring. Maka didapati kesimpulan sinergis dengan substansi data sebelumnya seperti terlihat dalam diagram dibawah ini;

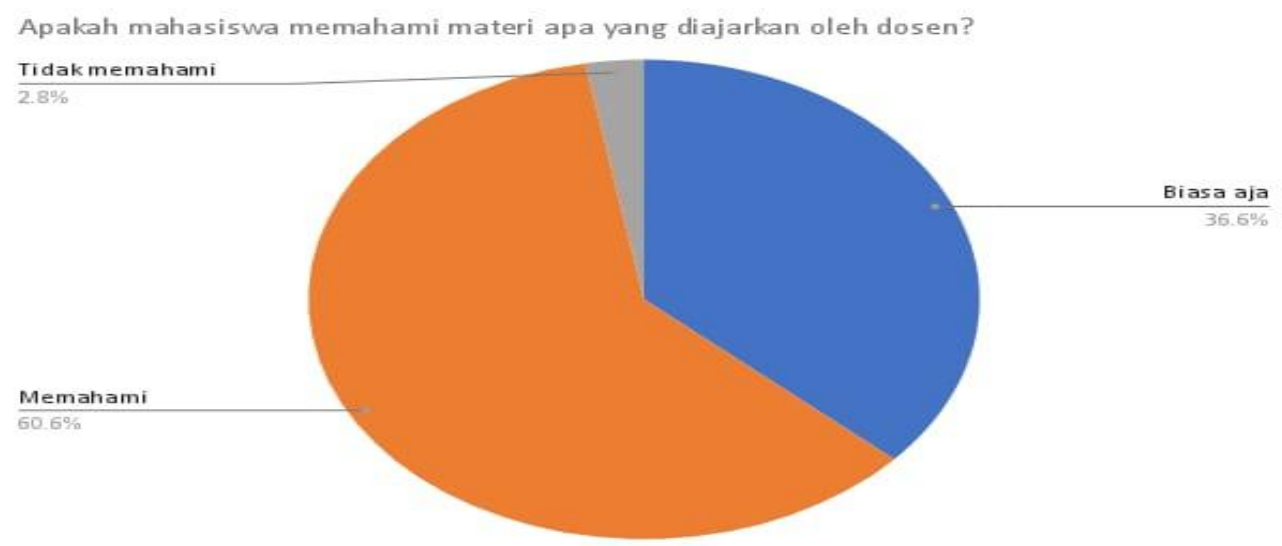

6o,6\% Mahasiswa mengatakan memahami materi yang diajarkan dosen saat pembelajaran daring berlangsung. Disusul 36,6\% mahasiswa mengatakan biasa saja, dan terdapat jawaban minor tidak memahami. Hal ini memperkuat data sebelumnya bahwa versi mahasiswa PG Paud bahwa pembelajaran daring saat ini berjalan secara efektif. Hal ini terbukti dengan jawaban diatas 6o\% mahasiswa mengatakan memahami materi yang diajarkan dosen.

Lebih mendalam lagi, peneliti menyajikan pertanyaan pada mahasiswa mengenai apakah mahasiswa dapat membuat kesimpulan atas materi yang diajarkan 
pada proses pembelajaran daring. Pertanyaan kuesioner ini dijawab oleh mahasiswa yang menunjukan data sinergis dengan asumsi pertama yakni pembelajaran daring berjalan dengan efektif. Adapun perolehan data pada pertanyaan ini sebagai berikut;

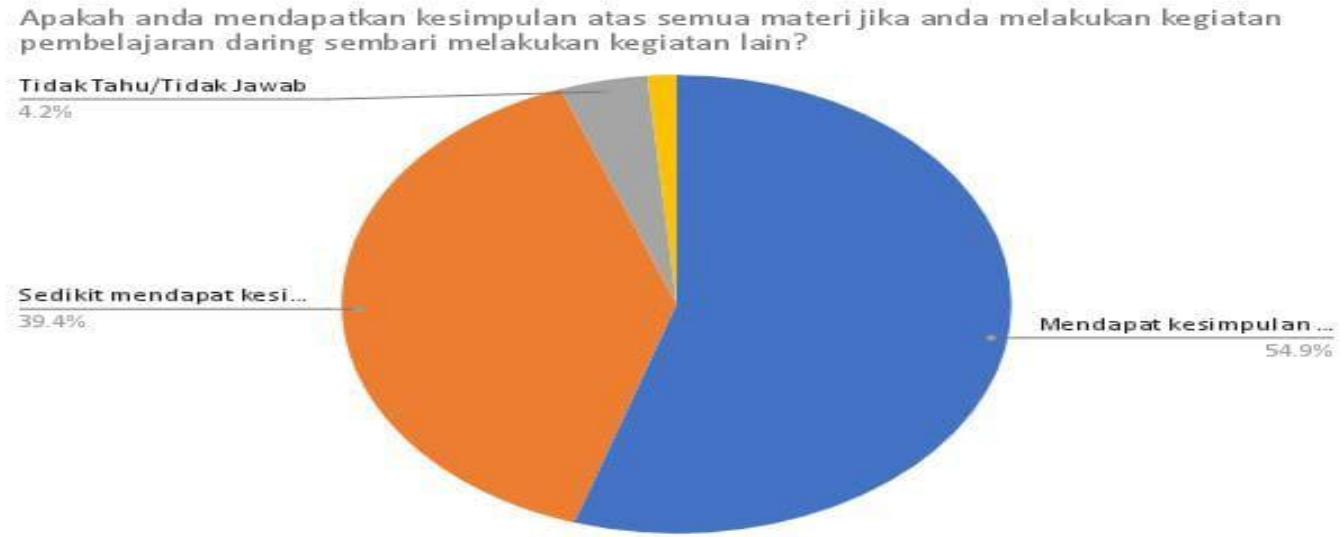

Menempati mayoritas menjawab mendapatkan kesimpulan materi dari proses pembelajaran daring. Mahasiswa menjawab mendapatkan kesimpulan materi sebanyak 54,9\% dan mahasiswa menjawab sedikit mendapatkan kesimpulan materi 39,4\%. Artinya masih sangat sinergis dengan asumsi bahwa sesungguhnya pembelajaran daring dapat dinilai masih efektif. Pertama, dari data ini mahasiswa menjawab mayoritas mendapatkan kesimpulan materi. Kedua, pada bagian mahasiswa menjawab sedikit mendapatkan kesimpulan materi, masih dapat diasumsikan sebagai efektifitas karena fenomena disini masih mendapakan materi.

Peneliti kemudian mencoba mengkonfirmasi perihal diterimanya kesimpulan materi oleh mahasiswa dari persepektif prosedur proses belajar-mengajar. Peneliti hadirkan pertanyaan apakah mahasiswa meluangkan waktu saat dilaksanakannya proses belajar mengajar secara daring. Pertanyaan ini peneliti angkat untuk dapat melihat bagaimana tingkat keseriusan mahasiswa dalam proses pembelajaran daring. maka di dapati data sebegai berikut;

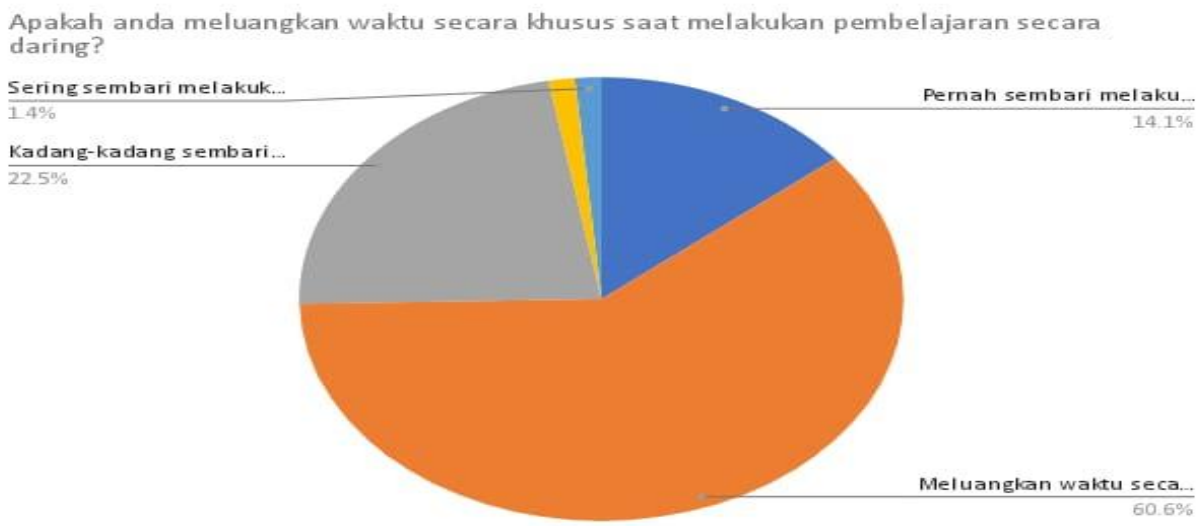

Pada diagram diatas terdeskripsikan mahasiswa meluangkan waktu secara khusus untuk melaksanakan pembelajaran daring. Total 6o,6\% mahasiswa menjawab meluangkan waktu khusus saat melakukan proses belajar-mengajar secara daring. 22.5\% mahasiswa menjawab terkadang sembari melakukan kegiatan lain. Kemudian 14,1\% mahasiswa mengatakan pernah sembari melakukan kegiatan ataupun aktivitas lain. 
Simpulan peneliti pada hasil jawaban apakah mahasiswa meluangkan waktu secara khusus diantaranya; pertama, masih dianggap sinergis dengan tujuan penelitian ini dilakukan yakni mengukur seberapa efektifkah pembelajaran daring dilakukan pada lokus ini. Jawaban atas ini adalah masih dianggap efektif, hal inipun diperkuat pada pokok bahasan ataupun temuan data pada diagram diatas. Kedua, sejumlah mahasiswa mengaku melakukan kegiatan daring sembari melakukan kegiatan lain menempati angka minoritas. Artinya dapat disimpulkan bahwa tingkat keseriusan mahasiswa pada proses pembelajaran daring dianggap tinggi. Terlepas pada konteks diatas, temuan ini menjadi kajian agar ditemukan formulasi keseriusan kedua belah pihak yakni mahasiswa dan dosen, sehingga pembelajaran dapat dilakukan secara alur manajemen, terjadwal, terkordinasi dan dapat difahami oleh mahasiswa.

Temuan lain menyambung pada pembahasan sebelumnya yakni mengenai durasi dosen mengajar pada proses pembelajaran daring. hal ini sengaja peneliti angkat untuk melihat efektifitas dari sudut pandang keseriusan dosen sebagai pemangku mata kuliah dan pemberi ajaran pada mahasiswa. Pada pembahasan ini didapati data sebagai berikut;

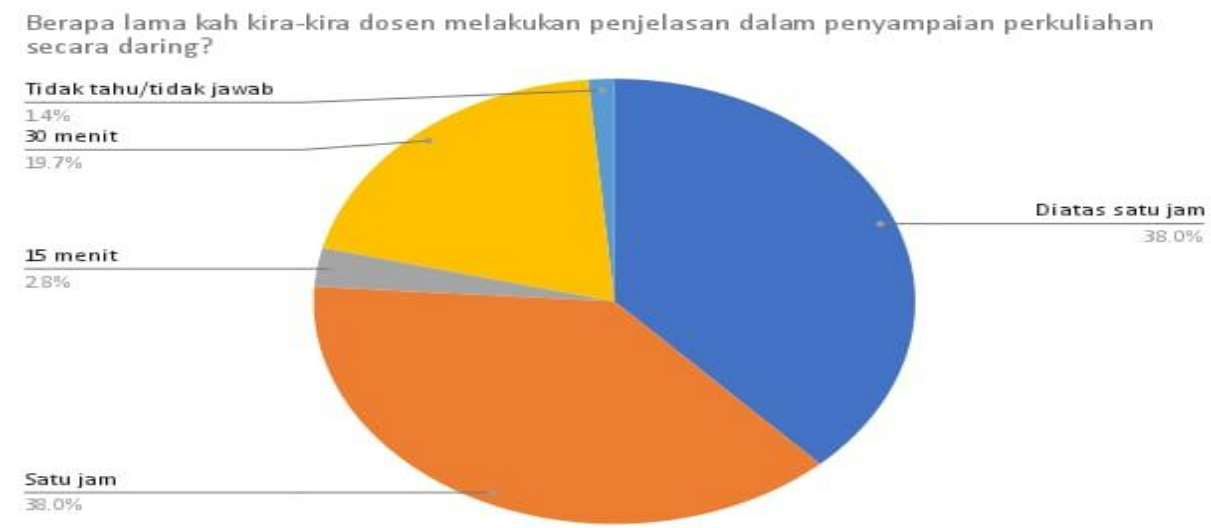

Jawaban mahasiswa bahwa dosen mengajar diatas satu jam adalah 38\%. Pada angka yang persis sama yakni 38\% mahasiswa lain menjawab durasi dosen mengajar satu jam. Sedangkan 19.7\% mahasiswa menjawab dosen mengajar 30 menit. Hal ini tentu harus menjadi bahan evaluasi bagi kampus khususnya prodi PG Paud di UMC. Karena tidak menutup kemungkinan dari mahasiswa yang menjawab sebelumnya kurang efektif, kurang puas, kurang memahami materi, ataupun kurang mendapatkan kesimpulan atas materi perkuliahan yang diajarkan bisa jadi disebabkan karena unsur dari dosen itu sendiri. Pada temuan data ini terdeskripsikan terdapat banyak dosen yang mengajar hanya satu jam dan dibawah satu jam.

Peneliti kemudian menyajikan pertanyaan kuesioner apakah didapati dosen dalam proses pembelajaran daring terjadi kesulitan. Terkait ini dapat dilihat dalam tabel sebagai berikut; 
Andi Ali Kisai, M. Azka Maulana \& Aip Syarifudin

Efektivitas Pembelajaran Daring......

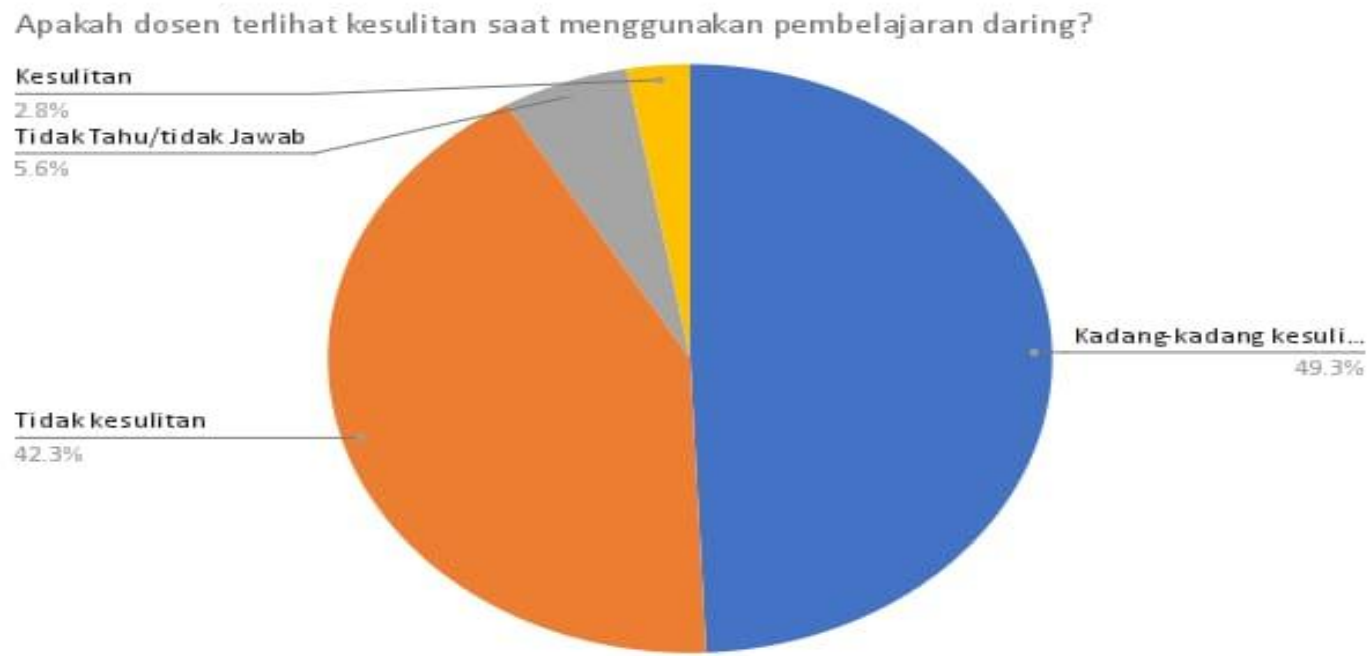

42,3\% mahasiswa menjawab tidak kesulitan, 35\% menjawab terkadang didapati keadaan dosen terlihat kesulitan dalam proses pembelajaran daring. Hal ini dapat disimpulkan bahwa jikapun evaluasi proses pembelajaran daring disematkan pada dosen maka tidak dapat dijustiifikasi karena unsur sistem ataupun media sebagai sarana proses pembelajaran daring. karena mayoritas mahasiswa menjawab tidak terjadi kesulitan dari dosen pengampu mata kuliah.

Data lapangan yang juga menunjukan sinergitas efektifitas pembelajaran daring terdapat pada jawaban atas pertanyaan lokus yang dipakai mahasiswa dalam proses pembelajaran daring. menempati mayoritas dari responden menjawab melakukan pembelajaran daring di rumah masing-masing sebanyak 93,0\%. Adapun cerminan data tersebut sebagai berikut;

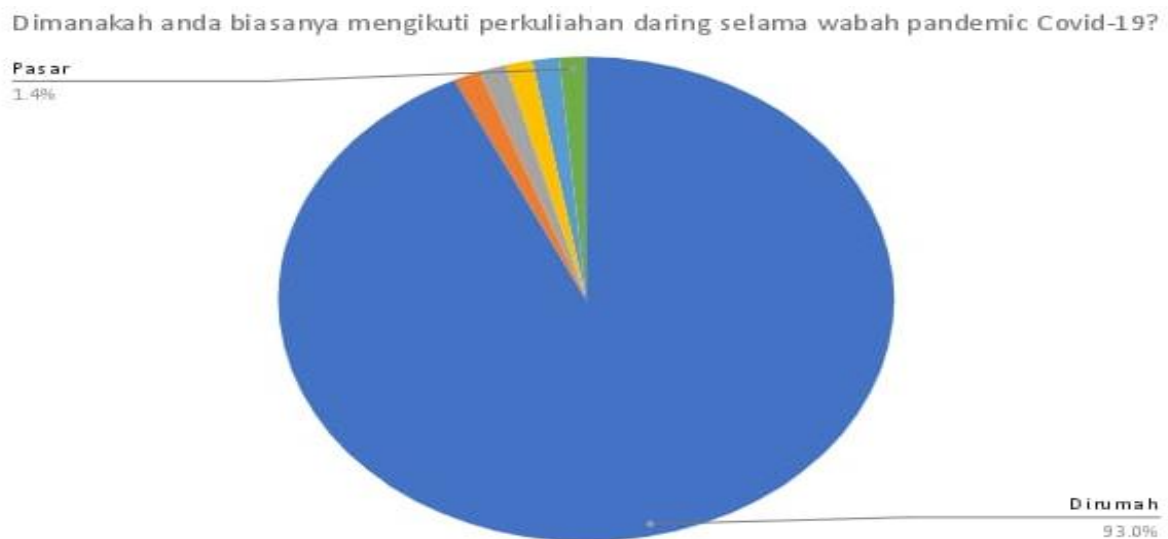

Berbanding lurus dengan data tersebut, data selanjutnya menunjukan lokus spesifik dirumah dilakukan pada ruang kerja/kamar sebanyak 74,6\%, disusul responden menjawab dilakukan di ruang tamu sebanyak 21, 1\%. Artinya dapat ditarik simpulan terdapat tingkat keseriusan pada mahasiswa dalam proses belajar metode daring dilihat dari sisi penggunaan lokus pembelajaran. 


\section{Manfaat Pembelajaran Daring di Perguruan Tinggi}

Terdapat keunikan pada penelitian ini, sejumlah data lain peneliti anggap memiliki esensi penting yang perlu diparhatikan secara seksama. Pada wilayah prinsip peneliti memandang secara garis besar metode pembelajaran daring memang dapat dikatakan efektif dengan sejumlah data lapangan yang telah dipaparkan sebelumnya diatas. Namun pada bagian ini peneliti akan ulas 'keunikan' data lapangan yang dapat menjadi bahan rekomendasi penelitian terkait proses pembelajaran metode daring yang telah berlangsung.

Pertama, fakta sejumlah mahasiswa menutup fitur layar camera pada pross berlangsungnya proses pembelajaran metode daring. data menunjukan sebanyak $52,1 \%$ mahasiswa mengakui bahwa kadang-kadang mematikan fitur layar camera. Data memperlihatkan pengakuan mahasiswa sering melakukan menutup fitur layar camera sebanyak 22,5\% dan mengakui pernah menutup fitur camera sebanyak 22.5\%. Hal ini peneliti pandang harus menjadi perhatian secara khusus karena ketika mahasiswa mematikan fitur layar kamera, pihak pengajar tidak dapat memastikan apakah mahasiswa mengikuti kegiatan belajar secara baik ataupun tidak. Diluar pada konteks data ini, pengalaman peneliti yang juga berperan sebagai pengajar merasa miris jika melakukan pembelajaran daring dengan sebagian mahasiswa menutup fitur layar camera. Pengalaman peneliti, pada keadaan ini beberapa mahasiswa yang sengaja ditanya pada saat pembelajaran daring tidak dapat menjawab/merespon adalah mereka yang menutup fitur layar camera.

Kedua, fakta apa yang dilakukan sejumlah mahasiswa saat pembelajaran daring dengan menutup fitur layar camera. Data menunjukan responden menjawab hanya menyimak materi perkuliahan sebanyak 39,4\%. Responden menjawab mencatat semua materi sebanyak $25,4 \%$, responden menjawab sembari melakukan aktifitas lain sebanyak 15,5\%. Responden tidak menjawab sebanyak 2,8\%, responden menjawab mencatat sekiranya penting menjawab 1,4\% dan responden menjawab menyimak dan mencatat sebanyak 1,4\%. Dengan demikian data menunjukan terdapat fenomena yang menunjukan fakta bahwa pada sebagian mahasiswa yang menutup fitur layar camera karena melakukan aktifitas lain.

Ketiga, fakta motif dibalik fenomena menutup fitur layar camera. Ketika pertanyaan ini lebih spesifik data menunjukan responden menjawab melakukan kegiatan lain sebanyak 26,8\%, kemudian responden menjawab malu membuka fitur layar camera sebanyak 35,2\%. Disusul dengan alasan-alasan lain seperti pada diagram dibawah ini;

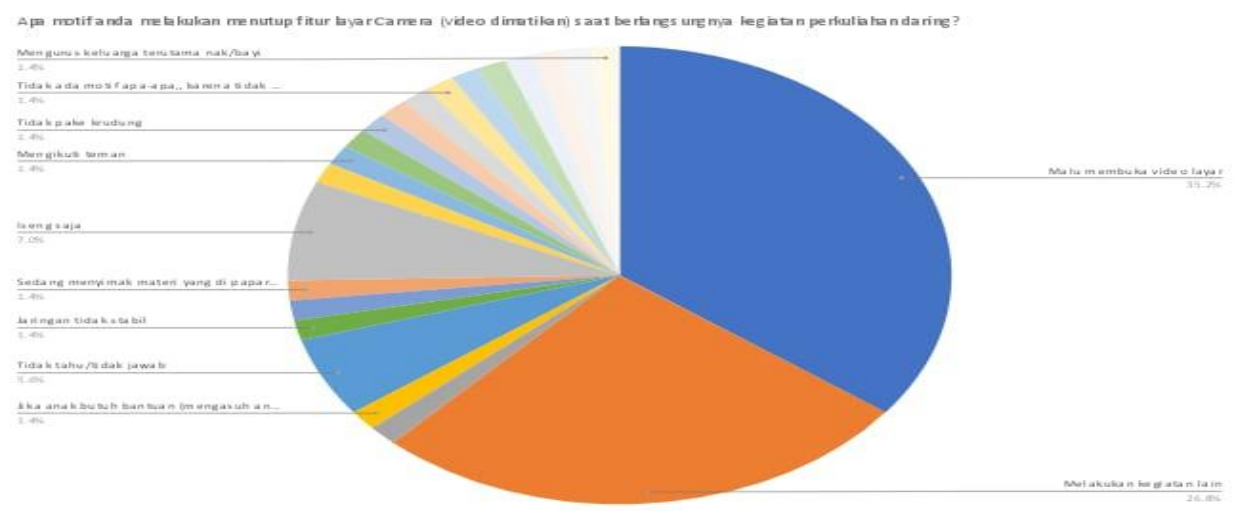


Keempat, fakta bahwa mayoritas pengajar melakukan pembelajaran daring dengan metode penyampaian materi dengan cara ceramah. Data menunjukan responden manjawab metode ceramah sebanyak 73,2\%. Padahal menurut peneliti metode ceramah dirasakan justru yang membuat sebagian mahasiswa merasa jenuh, kurang partisipatif, bahkan bisa jadi kejenuhan mahasiswa pada pembelajaran daring yang membuat perilaku mahasiswa menutup fitur layar camera. Peneliti pada bagian ini merekomendasikan metode brainstorming untuk memberikan stimulus partisipasi aktif dari peserta didik.

Kelima, fakta bahwa selama pandemic Covid 19 terdapat dinamika pembelajaran daring dari yang telah dicanangkan. Peneliti memberikan pertanyaan pada responden apakah pembelajaran daring terlaksana dengan baik yakni terstruktur, terjadwal, dan terkoordinasi. Pada pertanyaan ini responden menjawab cukup baik sebanyak 42,3\%, kemudian responden menjawab baik 32,4\%, responden menjawab kurang baik 14,1\%, responden menjawab sangat baik 9,9\%, dan sisanya menjawab tidak tahu/tidak menjawab. Dengan sajian data ini, dapat diketahui bahwa kedisiplinan proses pembelajaran yang sesuai penjadwalan, ketersesuaian dengan perangkat pembelajaran harus lebih ditingkatkan. Dengan demikian berpijak pada penelitian ini, peneliti merekomendasikan gagasan penelitian yang diilustrasikan pada bagan sebagai berikut:

\section{PEMBELAJARAN DARING PROGRAM STUDI \\ PG-PAUD TA 2020-2021 UMC}

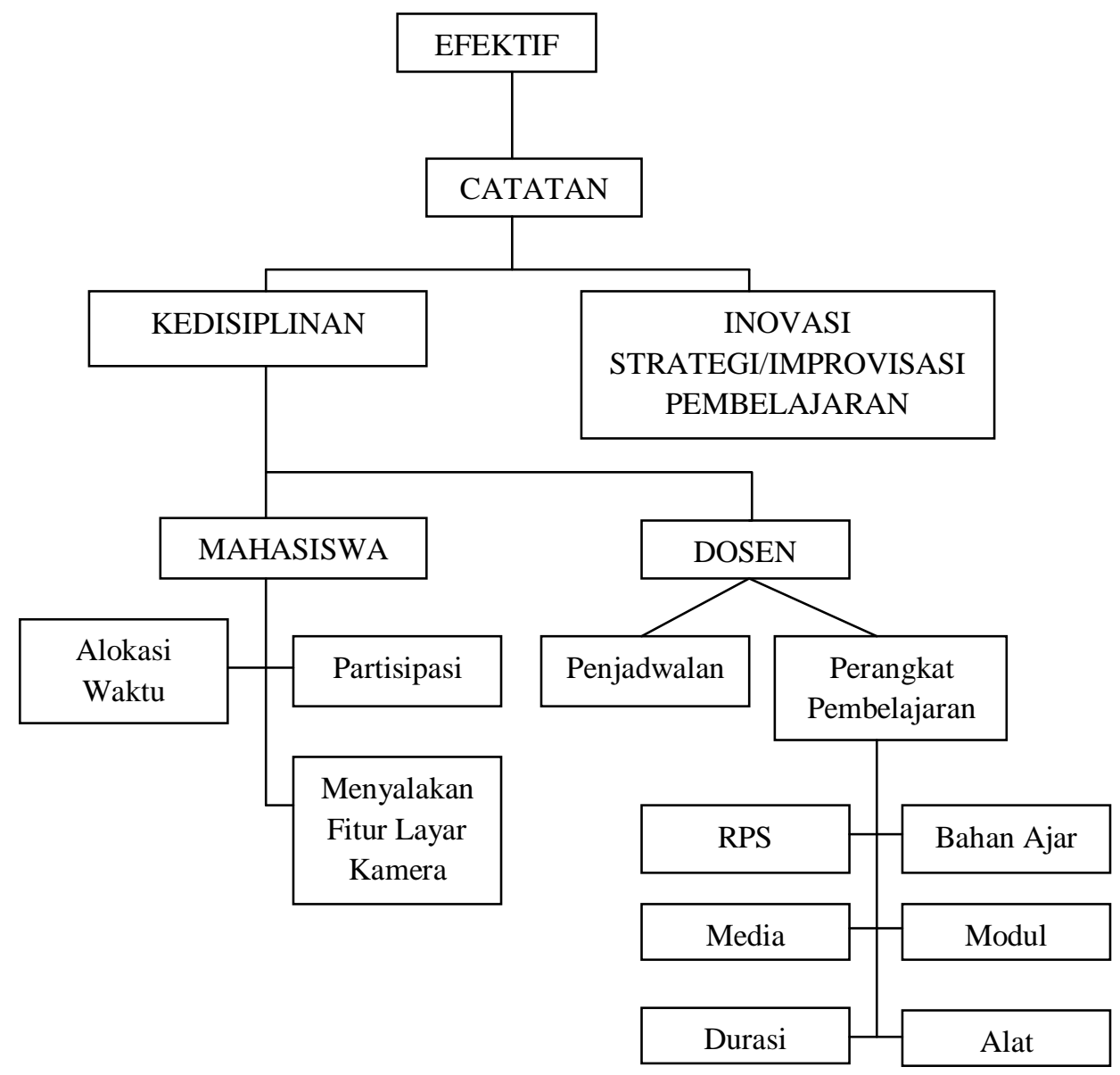


Kunci dari keberhasilan proses pembelajaran daring pada dua hal: pertama, kedisiplinan baik mahasiswa maupun dosen. Kedua, inovasi strategi/ improvisasi pembelajaran. Kedisiplinan pada mahasiswa antara lain menyangkut perlunya mahasiswa mengalokasikan waktu secara khusus disetiap jadwal pembelajaran daring, partisipasi aktif mahasiswa baik dalam diskusi maupun pada ruang media pembelajaran yakni menyalakan fitur layar kamera. Sedangkan kedisiplinan pada pihak pengajar yakni kedisiplinan dalam ketersesuaian penjadwalan pembelajaran, dan ketersesuaian dengan perangkat pembelajaran. Selain hal tersebut rekomendasi peneliti yakni perlunya inovasi strategi/improvisasi pembelajaran bagi pengajar. Hal ini berpijak dari data penelitian yang menunjukan fakta bahwa mayoritas menggunakan metode ceramah dalam proses pembelajaran daring. Peneliti merekomendasikan metode brainstorming agar memberikan stimulus partisipasi aktif dari mahasiswa.

\section{Simpulan}

Benang merah pada temuan data diatas adalah pembelajaran daring di Prodi PG Paud dapat dikatakan efektif. Disimpulkan oleh peneliti efektif karena beberapa alasan diantaranya; mayoritas responden menjawab efektif pembelajaran daring sebanyak 46,5\%, mayoritas responden merasa puas pada penyelenggaraan pembelajaran daring sebanyak 43,7\%, mayoritas responden dapat memahami materi yang disampaikan pada proses pembelajaran daring sebanyak 6o,6\%, mayoritas responden menjawab mendapatkan kesimpulan atas penyampaian materi pada pembelajaran daring sebanyak 54,9\%, mayoritas responden meluangkan waktu khusus pada proses pembelajaran daring sebanyak 6o,6\%, mayoritas responden menjawab durasi pembelajaran diatas satu jam sebanyak 38,0\%, mayoritas responden menjawab dosen tidak mengalami kesulitan pada proses pembelajaran daring sebanyak 42,3\%, mayoritas responden menjawab lokus pembelajaran daring dirumah 93,0\% dan mayoritas responden menjawab lokus dirumah secara spesifik pada proses pembelajaran daring di ruang kerja/kamar sebanyak 74,6\%.

Adapun peneliti simpulkan dari penelitian ini bahwa pembelajaran daring memiliki beberapa catatan, hal ini bersandar pada temuan data yang bersifat memperdalam fakta dilapangan. Antara lain, fenomena sejumlah mahasiswa menutup fitur layar camera pada saat pembelajaran daring berlangsung, fenomena sejumlah mahasiswa melakukan kegiatan lain disaat pembelajaran daring berlangsung, fenomena metode yang digunakan dominan adalah metode ceramah, dan fenomena bahwa terjadinya dinamika penjadwalan perkuliahan selama pandemic covid-19. Keadaan lain justru memperlihatkan adanya jadwal yang bersamaan dengan mata kuliah lain.

Peneliti memandang perlu adanya kedisiplinan dan inovasi pembelajaran/ strategi improvisasi pembelajaran. Kedisiplinan harus dilakukan oleh kedua belah pihak, yakni mahasiswa dan dosen sebagai pengajar. Mahasiswa harus mengikuti proses pembelajaran daring secara serius. Hal ini meliputi dari alokasi waktu secara khusus, kepastian keterlibatan partisipasi aktif dalam proses belajar (termasuk menyalakan fitur layar camera) dan hal lainnya. Pada pihak pengajar, peneliti merasa perlu adanya evaluasi dan pendisiplinan pada dosen sehingga memerhatikan 
luaran dari proses belajar-mengajar. Pada evaluasi ini bila diperlukan sampai pada tahap evaluasi media pembelajaran, kedisiplinan durasi waktu pengajaran, mekanisme penyertaan tugas, pembuatan bahan ajar dan khususnya ketepatan waktu sesuai penjadwalan.

\section{DAFTAR PUSTAKA}

Argaheni, Niken Bayu. Sitematik Review: dampak perkuliahan daring saat pandemic covid-19 terhadap mahasiswa Indonesia PLACENTUM Jurnal Ilmiah Kesehatan dan aplikasinya Vol 8 (2) 2020

Arnesti, N., \& Hamid, A. (2015). Penggunaan Media Pembelajaran Online - Offline Dan Komunikasi Interpersonal Terhadap Hasil Belajar Bahasa Inggris. Jurnal Teknologi Informasi \& Komunikasi Dalam Pendidikan, 2(1). https://doi.org/10.24114/jtikp.v2i1.3284

Darmalaksana, W., Hambali, R., Masrur, A., \& Muhlas, M. (2020). Analisis Pembelajaran Online Masa WFH Pandemic Covid-19 sebagai Tantangan Pemimpin Digital Abad 21. Karya Tulis Ilmiah (KTI) Masa Work from Home (WFH) Covid-19 UIN Sunan Gunung Djati Bandung, 1-12. http://digilib.uinsgd.ac.id/id/eprint/30434

He, W., Xu, G., \& Kruck, S. E. (2019). Online IS education for the 21st century. Journal of Information Systems Education, 25(2), 1. https://aisel.aisnet.org/jise/vol25/iss2/

Hikmat, Hermawan, Endang, Aldim, Irwandi. (2020). Efektivitas Pembalajaran Daring Selama Masa Pandemi Covid-19: Sebuah Survey Online. UIN Sunan Gunung Djati Bandung. http://digilib.uinsgd.ac.id/id/eprint/30625

Saifuddin, M. F. (2016). E-Learning Dalam Persepsi Mahasiswa. Universitas Ahmad Dahlan. 102-110.

Sugiyono, 1999. Metode Penelitian Administrasi. Edisi kedua. Bandung: Alfabeta

Sugiyono, 2014. Metode Penelitian Pendidikan Pendekatan Kuantitatif, Kualitatif dan R\&D. Bandung. Alfabeta

Siregar, H.S et al, 2020. Merekonstruksi alam dalam kajian sains dan agama: Studi kasus pada masa Pembatasan Sosial Berskala Besar (PSBB) dampak Covid-19. Digital Library UIN Sunan Gunung Djati Bandung. http://digilib.uinsgd.ac.id/id/eprint/307oo

Syarifudin, A. S. (2020). Impelementasi Pembelajaran Daring Untuk Meningkatkan Mutu Pendidikan Sebagai Dampak Diterapkannya Social Distancing. Jurnal Pendidikan Bahasa dan Sastra Indonesia Metalingua, 5(1), 31-34. https://doi.org/10.21107/metalingua.v511.7072

Steers (1985:87) Efektivitas Organisasi Kaidah Perilaku (Alih bahasa Magdalena). Jakarta: Erlangga

Palvia, S., Aeron, P., Gupta, P., Mahapatra, D., Parida, R., Rosner, R., \& Sindhi, S. (2018). Online education: Worldwide status, challenges, trends, and implications. https://doi.org/10.1080/1097198X.2018.1542262

Permendikbud No 109 Tahun 2019 tentang Penyelenggaraan Pendidikan Jarak Jauh UU Republik Indonesia No 20 Tahun 2003 Tentang Sistem Pendidikan Nasional 
https://www.kompas.com/tren/read/2021/o7/18/104500065/update-corona-18-juli-500.ooo-kasus-aktif-covid-19-di-indonesia-inggris (diakses 19/07/2021)

https://www.suara.com/news/2021/o7/16/182349/resmi-pemerintah-perpanjangmasa-ppkm-darurat-hingga-akhir-bulan-ini (diakses pada 19/o7/2021)

https://jurnalpost.com/dilema-mahasiswa-selama-belajar-daring-di-masapandemi/23318/ (diakses 19/o7/2021)

https://www.republika.co.id/berita/qvgkls374/optimisme-penggiat-pendidikantinggi-di-tengah-pandemi (diakses 19/o7/2021)

http://fppb.ubb.ac.id/berita--.html (diakses 19/o7/2021) 